\title{
Asterias Rubens (Echinoderm): Evidence of Lymphocytes, Lymphokines and Invertebrate Primitive Antibody(IPA).Expected Rôle of Tiedemann's Bodies
}

Michel Leclerc*

Immunology of Invertebrates, Div : Biochem/Biology, Orléans University (France)

*Corresponding author: Michel Leclerc, Immunology of Invertebrates, Div : Biochem/Biology, Orléans University (France)

Received date: 3 November, 2021 | Accepted date: 12 November, 2021 | Published date: 15 November, 2021

Citation: Michel Leclerc. (2021) Asterias Rubens (Echinoderm): Evidence of Lymphocytes, Lymphokines and Invertebrate Primitive Antibody (IPA). Expected Rôle of Tiedemann's Bodies. J Virol Viral Dis 1(1). doi https://doi.org/10.54289/JVVD2100104

Copyright: (C) 2021 Michel Leclerc. This is an open-access article distributed under the terms of the Creative Commons Attribution License, which permits unrestricted use, distribution, and reproduction in any medium, provided the original author and source are credited.

\begin{abstract}
The axial organ is considered as ancestral lymphoïd organ. It contains T and B sea star lymphocytes and Phagocytes. It plays a fundamental rôle in the sea star cell-mediated immune responses and humoral immune ones.Asterids belong to Echinoderma (Invertebrates).An expected rôle of Tiedemann's bodies is evoked.
\end{abstract}

Keywords: Invertebrates; Echinoderms; I.P.A; Lymphocytes; Lymphokines; Lymph nodes; Tiedemann's bodies

\section{Introduction:}

The position of the echinoderms, in particular, has been a matter of doubt and controversy in the studies of the vertebrate ancestors [1].

Sea-stars belong to the class Asteroidea of the phylum Echinoderma : Asterias rubens was studied.

They are marine animals, also named starfishes. They possess a primitive lymphoïd organ:

The axial organ which lies along the stone canal, the Tiedemann's bodies ( 2 per interradius:total : 8) situated in the ring canal of the oral part .

The structure of the axial organ is glandular, spongy and crossed by connective tissue.

Many follicles of heterogeneous size with clear zones are lined by cellular cords. We find a similar structure inside the Tiedemann's bodies: they evoke lymph nodes.A schema represents these last ones in Fig.3

The various types of cells present in the axial organ have been studied in our laboratory, by optical and electron microscopy
(S.E.M and T.E.M).

Essentially two types of cells are found in T.E.M [2]:

Cells which morphologically resemble mammal lymphocytes (Fig.1) (Fig .2).

\section{Evidence of Lymphokines:}

The method of Leiper and Solomon [3] was used, with some modifications.Cells were separated by nylon wool and were cultured for $24 \mathrm{~h}$ at $10^{\circ} \mathrm{C}$ in the presence of PWM-coated Sepharose beads. Supernatants from these cultures were centrifuged to eliminate beads and debris, sterilized by membrane filtration (0.22- $\mu \mathrm{m}$ Millipore) and concentrated 5or 10-fold with an ultrafiltration device (Amicon) fitted with «PM-10 Diaflo » membranes. Supernatant controls were obtained from cells cultured with non-coated beads, from cells cultured alone and from beads cultured alone. The supernatants were added to cultures of total axial organ cells which had been started $24 \mathrm{~h}$ before, and $24 \mathrm{~h}$ later, the cells were harvested and mitogenic stimulation was evaluated by measuring tritiated-H-methyl-thymidine incorporation. 


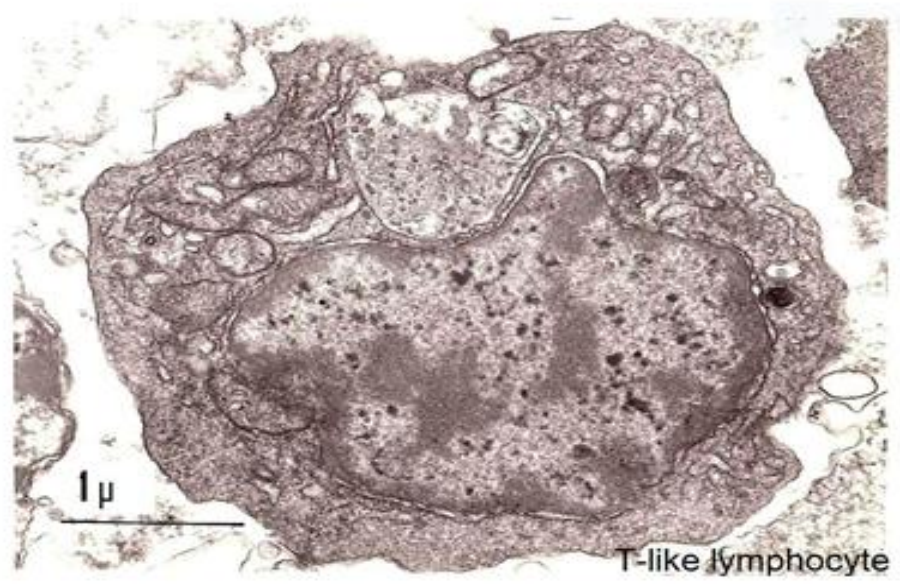

Figure 1

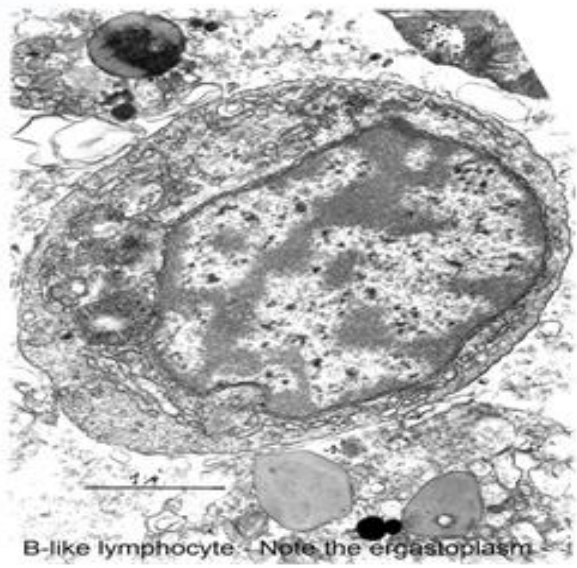

Figure 2

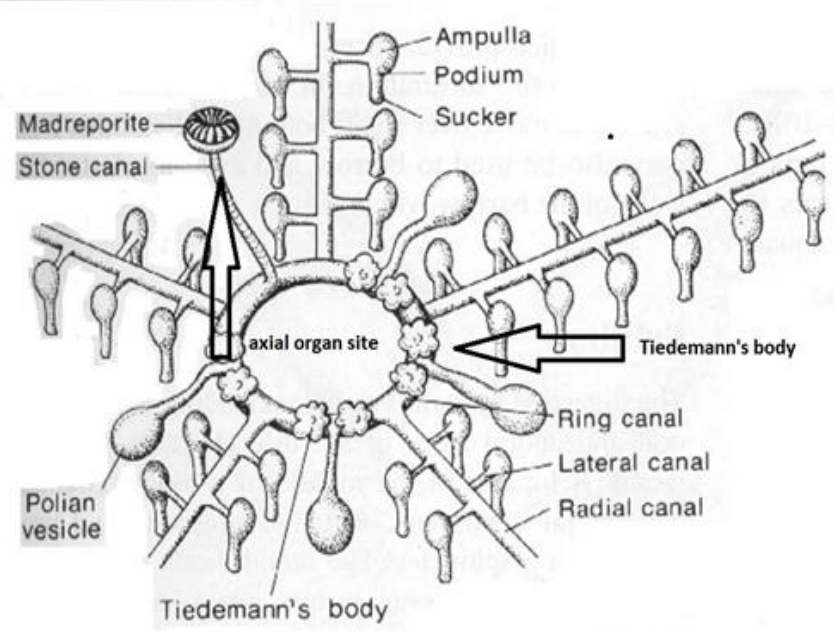

Figure 3

It was found that the the supernatant from the non-adherent cells cultured in the presence of PWM beads stimulated the total axial organ cells. No stimulation was observed in the various controls. This result indicates that non-adherent cells (i-e sea star T lymphocytes) produce a lymphokine mediator which is able to stimulate the total axial organ cells. The active substance was inactivated by trypsin and chemotrypsin, or by heating for $1 \mathrm{~h}$ at $70{ }^{\circ} \mathrm{C}$, but it resisted at $56^{\circ} \mathrm{C}$ [4]. studies [6].

Evidence of Humoral responses: Notion of IPA (Invertebrate primitive antibody:

In a first study [7], it was shown that the Asterina gibbosa axial organ cells, previously injected with horse-radish peroxidase (HRP) were able to react specifically with the same enzyme. This observation was made by T.E.M, using an immunocytochemical technique.A similar result was later observed with the Asterid : Asterias rubens. Since a variety of antigens, were injected in the coelomic cavity, near the axial organ of Asterids, such as: E. coli alkaline phosphatase, bovine serum albumin, rat IgG, human lambda Bence-Jones protein, myoglobin, and more recently, the haptens: TNP and FITC coupled to polyacrylamide beads. Results were summarized in 2012 [8]. We identified an invertebrate primitive antibody, characteristics of which were: specificity and structure (2 Ig sites) after its (Sea star) invertebrate primitive 
antibody, characteristics of which were: specificity and structure (2 Ig sites) after its (sea star) immunization to HRP and genomic research [9]: The gene showed a specific immune response to the enzyme HRP after its insertion in an Escherichia coli plasmid [10]. Moreover Fab gene, Fc receptor gene, $\mathrm{Cr}$ gene and $\mathrm{MHC}$ genes were recently discovered [11].

\section{Conclusion:}

The general idea that emerges from the experiments reported in the present review is that Echinoderma, as exemplified by the sea star: Asterias rubens, possess an ancestral lymphoïd organ: the axial organ. It appears that all the elements necessary to immune responses (phagocytic cells, T sea star lymphocytes, B lymphocytes) are present in this organ which initiates: lymphokines, humoral immune responses (invertebrate primitive antibody: IPA) of the sea star.We suppose now that immune responses occur also from Tiedemann's bodies which may be compared to Vertebrate lymph nodes. At the begining these structures were considered as enigmatic [12] Further studies are necessary to confirm or to infirm the idea they are resembling to vertebrate lymph nodes.

\section{References.}

1. Kampmeier OF. (1969) Evolution and comparative morphology of the lymphatic system p.72 in Charles C. Thomas, Springfield.

2. Anteunis A, Leclerc M, Vial M, et al. (1985) Cell.Biol.Int.Rep. 9(7): 663-670.

3. Leiper JB, Solomon JB. (1977) Asterias rubens (Echinoderm): Evidence of Lymphocytes, Lymphokines and Invertebrate Primitive antibodyImmunology. 32: 215-226.
4. Leclerc M, Brillouet C, Luquet G, et al. (1981) Properties of Cell Subpopulations of Starfish Axial Organ: In Vitro Effect of Pokeweed Mitogen and Evidence of Lymphokine-like Substances Scand J Immunol. 14: 281-284.

5. Legac E, Vaugier GL, Bousquet,F, et al. (1997) Current Knowledge on the Development and Functionality of Immune Responses in the European Sea Bass (Dicentrarchus labrax) Scand.J.Immunol. 44: 375-380.

6. Leclerc M, Amer J. (2012) Innate and Adaptative Immunity in the Sea-Star Asterias Rubens Immunol. 8(3): 78-83.

7. leclerc M, Ann. (1973) Injections of Various Antigens (Bj, Hrp, Alkaline Phosphatase, Bovine Serum Albumine). Evidence of Antibody Reactions in The Sea Star Immunol.124(3): 363-74.

8. leclerc M, Amer J. (2012) Humoral Immune Responses to Various Antigens In The Asterids: A. Gibbosa And A.RubensImmun. 4: 196-199.

9. Vincent N, Osteras M, et al. (2014) A new gene in A. rubens: A sea star Ig kappa gene Metagene. 2: 320-322.

10. Leclerc M, Otten P. (2014) Asterias rubens (Echinoderm): Evidence of Lymphocytes, Lymphokines and Invertebrate Primitive antibody SAJ Biotechnology. 1: 1-3.

11. Leclerc M, Baerlocher L. (2021) Mapping on Sea-Star MHC Genes in Invertebrates Ejbio. 2 (2): 60-62.

12. Ferguson JC, Biol Bull. (1984) Translocative Functions of the Enigmatic Organs of Starfish: The Axial Organ, Hemal Vessels, Tiedemann's Bodies, and Rectal Caeca: An Autoradiographic Study 166: 140155. 